\title{
INOVASI DAN STRATEGI UNTUK MENGURANGI PENGARUH BANJIR PADA USAHATANI PADI
}

\section{Innovation and Strategies to Eliminate Flood Effects on Rice Farming}

\author{
Abdul Karim Makarim* dan Ikhwani \\ Pusat Penelitian dan Pengembangan Tanaman Pangan \\ Jl. Merdeka 147 Bogor
}

\begin{abstract}
Impacts of flash floods on lowland rice fieldsare becoming worsen (increase in areal affected, severity and frequency) from year to year caused significantly decrease in rice yield, rice production and farmers' incomes losses. The objectives of this study are (1) to collect information on the effects of flash floods on rice yield, rice production and farmers' income losses at the present and at the future with and without adaptation measures; (2) to identify required and innovation technology; (3) to set strategies to reduce and to overcome the impacts of flash floods on rice farming. Data and information were collected fromsix rice farmingin West Java and Central Java in 2010. Analyses were also done using a mathematical model, and a dynamic simulation model RENDAMAN.CSM to get information on predicted losses of rice yield, of rice production and of farmers' incomedue to flash flood until year 2020. Floods and submergence during year 2006 to 2010 reduce rice yield in West Java as much as 2.5 ton ha $\mathrm{h}^{-1}$ and in Central java as much as 3.0 ton ha ${ }^{-1}$. Income losses from rice farming in West Java and Central Java estimated between Rp. 6.5 and Rp. 7.0 millions ha ${ }^{-1}$. Rice production losses due to flood varied between 10 46 thousands ton of harvest dry grains, or equal to Rp. 24-112 milyard year ${ }^{-1}$. Those losses are predicted continually increasing if there is no adaptation action will be taken; grain losses will reach 12-58 thousands ton harvest dry grains, or equal to Rp. 30-140 milyar inyear 2015. The urgent rehabilitation steps required to overcome the flood impacts are: (1) conservation and rehabilitation of watershed areas intensively from head to tail; (2) improvement of infrastructure: irrigating and drainage canals from head to tail by the central government, including removal mud deposits on the canal floor by the local government; (3) mobilization of local farmers' groups (gotong royong) to keep the canal clean and well functioning with water vegetation removal; (4) reevaluate one year crop rotation, and determine the beginning of the planting season; (5) providing water pumps to remove the excessive flood water from the rice fields or to irrigate rice field during dry period. Innovative technology required for adaptation measures are (1) rice varieties tolerate to submergence for more than 10 days; (2) application of slow release or briquette $N$ fertilizers and the other nutrients at the correct time; (3) preparing good and healthy seedlings for replacing the missing or dead hills due to flooding; (4) rearrange plant spacing or plant population to eliminate crop damage and to fasten recovery after submergence; and (5) requires technology to overcome golden snail and the other pests which become common during and after submergence. Those technologies need improvement on their efficacy from now to face the future worse flood condition.
\end{abstract}

Keywords: Flood, innovative technology, lowland rice, strategy

\begin{abstract}
ABSTRAK
Pengaruh banjir pada lahan padi sawah kian semakin buruk (bertambahnya luas area terdampak, keparahan, dan frekuensinya) dari tahun ke tahun, menyebabkan penurunan secara nyata hasil padi, produksi padi dan pendapatan petani. Tujuan penelitian ini adalah (1) mengumpulkan informasi pengaruh banjir terhadap hasil padi, produksi padi dan penurunan pendapatan petani padi akibat banjir saat sekarang hingga nanti, dengan dan tanpa tindakan adaptasi; (2) mengidentifikasi teknologi inovasi yang diperlukan untuk mengatasi banjir; (3) membuat strategi untuk mengurangi dan mengatasi dampak banjir pada pertanaman padi sawah. Data dan informasi dikumpulkan dari enam lahan sawah di Jawa Barat dan Jawa Tengah pada tahun 2010. Analisis dilakukan menggunakan model matematik dan model simulasi dinamik RENDAMAN.CSM, untuk memperoleh informasi dugaan besarnya kehilangan hasil, produksi dan kerugian usahatani padi hingga tahun 2020. Banjir dan rendaman selama tahun 2006-2010 menurunkan hasil padi di Jawa Barat 2.5 ton ha ${ }^{-1}$, dan di Jawa Tengah 3.0 ton ha ${ }^{-1}$. Kerugian yang dialami petani di Jawa Barat dan Jawa Tengah berkisar antara Rp. 6.5-7.0 juta ha ${ }^{-1}$. Kehilangan produksi padi akibat banjir 10-46 ribu ton GKP, atau setara Rp. 24-112 milyar tahun ${ }^{-1}$. Kehilangan produksi ini diduga akan terus meningkat bila tanpa adanya tindakan adaptasi menjadi 12-58 ribu ton GKP atau setara Rp. 30-140 milyar pada tahun 2015. Langkah pengendalian menghadapi banjir yang segera diperlukan adalah (1) konservasi dan perbaikan DAS hulu hingga hilir secara intensif; (2) perbaikan infrastruktur saluran irigasi dan drainase dari hulu ke hilir oleh pemerintah pusat dan daerah, termasuk pengerukan endapan lumpur; (3) gerakan gotong royong pemeliharaan saluran berupa pembersihan tumbuhan air dalam saluran (eceng gondok dan sebagainya) oleh kelompok-kelompok tani dan masyarakat; (4) mengevaluasi kembali pola rotasi
\end{abstract}


tanaman dalam setahun termasuk awal musim tanam; (5) penyediaan pompa-pompa pembuang air banjir. Perubahan teknologi yang diperlukan sebagai tindakan adaptasi terhadap banjir adalah (1) penggunaan varietas tahan rendaman lebih dari 10 hari, dengan kualitas gabah dan harga jual sesuai dengan keinginan petani; (2) perbaikan pupuk dan pemupukan, seperti penggunaan pupuk $\mathrm{N}$ lepas lambat (slow release), atau briket, hara lain dan waktu pemberian yang tepat; (3) penyiapan bibit sehat dan kuat yang siap disulamkan apabila terjadi kerusakan pertanaman akibat banjir; (4) perbaikan cara budidaya seperti pengaturan jarak tanam/populasi untuk mengurangi kerusakan/kerugian akibat banjir/rendaman; dan (5) cara pengendalian keong mas dan hama penyakit lain yang berkembang cepat akibat banjir. Teknologi di atas perlu terus diperbaiki efektivitasnya dari sekarang untuk menghadapi kondisi banjir yang lebih parah di masa mendatang.

Kata kunci: Banjir, teknologi inovasi, padi sawah, strategi

\section{PENDAHULUAN}

Dampak banjir pada lahan sawah di lokasi tertentu semakin meluas dan intensif dari tahun ke tahun, telah menyebabkan kerugian yang cukup berarti bagi petani (Departemen Pertanian, 2009). Hal ini berhubungan dengan perubahan iklim global, dan kerusakan lingkungan. Dampak perubahan iklim global bumi yang telah terdeteksi dan berpengaruh terhadap produksi padi di Indonesia adalah (a) kenaikan suhu udara di permukaan bumi; (b) curah hujan ekstrim yang eratik, (c) naiknya permukaan air laut yang menyebabkan banjir langsung maupun tidak langsung akibat terhambatnya arus sungai; dan (d) sering terjadi bencana alam. Dalam bidang pertanian dengan lebih seringnya terjadi banjir yang merendam lahan-lahan sawah mengakibatkan kegagalan atau menurunkan produksi padi setempat.

Data dan informasi yang dikumpulkan dari enam studi kasus dampak banjir pada usahatani padi yang dilaksanakan tahun 2010 di Kabupaten Subang, Karawang, Indramayu (Jawa Barat), dan Sragen, Demak, dan Pati (Jawa Tengah). Hasil analisis menggunakan model matematik dan model simulasi dinamik RENDAMAN.CSM (Makarim, 2003), diperoleh informasi aktual dan dugaan berupa besarnya kehilangan hasil, produksi dan kerugian usahatani padi hingga tahun 2020. Berdasarkan hal tersebut diberikan saran tindakan yang diperlukan untuk mengantisipasi, menanggulangi dan mengadaptasi teknologi untuk menghadapi dampak banjir pada usahatani padi.

\section{Banjir dan Kekeringan di Lahan Pertanian}

Ada tiga faktor dominan aspek terkait banjir dan kekeringan pada lahan sawah yaitu (1) iklim, (2) hidrologi dan (3) agronomi.

1. Iklim. Letak geografis Indonesia di antara dua benua dan dua samudera serta terletak di sekitar garis khatulistiwa, menyebabkan Indonesia berada pada belahan bumi beriklim monsoon tropis yang sangat sensitif terhadap anomali iklim, yaitu (a) El-Nino Southern Oscillation (ENSO), (b) Indian Ocean Dipole Mode (IOD), dan (c) Median Jullien Oscillation (MJO). ENSO menyebabkan terjadinya kekeringan apabila menghangat (El Nino), atau banjir jika pendinginan (La Nina). IOD positif menyebabkan curah hujan rendah dan IOD negatif menyebabkan curah hujan tinggi di wilayah Indonesia bagian selatan. Sementara, MJO berpengaruh pada awal musim hujan yang dimulai dari bagian barat Sumatera bergerak terus ke timur.

Adanya pengaruh perubahan iklim global berupa peningkatan suhu rata-rata atmosfir, laut, dan daratan bumi sebesar $0.74 \pm 0.18{ }^{\circ} \mathrm{C}$ dalam seratus tahun terakhir, akibat meningkatnya konsentrasi gas-gas rumah kaca (IPCC, 2007). Kenaikan suhu antara tahun 1990 dan 2100 diduga terjadi antara 1.1 hingga $6.4{ }^{\circ} \mathrm{C}$ (Hart and John, 2006). Kenaikan suhu ini sangat luas dampaknya terhadap lingkungan di bumi serta berpengaruh "secara berantai" terhadap semua aktivitas, termasuk pertanian. Banjir dan kekeringan sangat berpengaruh terhadap produksi dan produktivitas hasil pertanian.

2. Hidrologi. Wilayah banjir di Indonesia yang sebagian besar berada di daerah aliran sungai (DAS) dan umumnya tersebar di dataran rendah dataran banjir (flood plain) dan daerah pantai kondisi hidrologisnya mengalami kerusakan dan berdrainase buruk. sepanjang wilayah sungai terutama. Banjir di Pulau Jawa akibat kerusakan DAS, contohnya DAS Bengawan Solo, Brantas, dan juga di Ngawi, Kediri, Madiun, Bojonegoro, Lamongan, Sragen, Kudus dan sebagainya.

3. Agronomi. Kekeringan atau kebanjiran pada komoditas pertanian merupakan resultan antara ketersediaan air (KA) dan kebutuhan air pertanaman (KAP) atau ditulis KA - KAP.

(a) Bila KA - KAP negatif $(<0)$, maka pertanaman akan mengalami kekeringan;

(b) Bila sama atau sedikit positif artinya pertanaman cukup air; sedangkan

(c) Bila $>0$ (jauh di atas 0) ada kemungkinan terjadi kelebihan air atau banjir.

Kebutuhan air pertanaman (KAP) suatu area dapat diatur. Jumlah KAP dipengaruhi oleh luas areal pertanaman dan jenis komoditas. Kebutuhan air tanaman/komoditas per hari dan umur sejak tanam hingga panennya menentukan jumlah kebutuhan air, sehingga pemilihan komoditas, varietas dan luasannya masingmasing dalam suatu hamparan menentukan KAP, yang berarti juga merupakan tindakan adaptasi terhadap kebanjiran atau kekeringan.

Apabila KA dianggap tertentu jumlahnya (given) namun berbeda jumlah per bulannya, maka penyesuaian yang harus dilakukan agar tidak terjadi kekeringan adalah sebagai berikut: (a) memilih komoditas yang kebutuhan airnya sedikit; (b) mengurangi areal tanam; (c) kombinasi 
antara a dan b merupakan pola pertanaman ideal untuk suatu wilayah pada kondisi ketersediaan air tertentu.

\section{Studi Kasus di Jawa Barat (Kabupaten Kerawang, Subang dan Indramayu)}

\section{Permasalahan}

Banjir di Jawa Barat terutama disebabkan oleh (a) dua faktor input atau sumber pemasukan air, yaitu air hujan dan air limpasan dari desa-desa lain di hulu; dan (b) satu faktor output yaitu drainase kurang atau saluran pembuangan air tidak berfungsi normal.

Penyempitan saluran pembuangan air karena banyak pengendapan tanah, sehingga kecepatan air pembuangan lambat atau bahkan terhenti, daya tampung air berkurang sehingga air mudah meluap atau banjir. Oleh sebab itu, diperlukan pengerukan saluran pembuangan secara tuntas.

Proyek pengerukan saluran pembuangan tidak tuntas, tidak sesuai dengan kebutuhan sehingga pengerukan tidak efektif. Saluran pembuangan ini sebenarnya dapat dijadikan sumber air untuk padi dan tanaman lainnya di musim kemarau meskipun dalam luasan terbatas. Namun, adanya endapan-endapan tanah dalam saluran mengurangi daya tampung air.

Dalam skala kecil adanya jembatan/penyempitanpenyempitan di saluran pembuangan juga sebagai penyebab banjir, karena menghambat aliran air, sehingga air melimpah ke sawah (Dinas Pengelolaan Sumberdaya Air, 2009).

Puncak musim hujan (Januari dan Pebruari) sebagai faktor utama banjir secara alami di Cibuaya karena menyebabkan limpasan air di hulu sungai. Sistem pembuangan dari hulu, tengah, hilir seharusnya dapat diatur, yang tidak terkendali sehingga tidak terjadi limpahan air. Banjir tahunan menjadi bertambah dengan adanya masalah hama keong mas pada pertanaman padi. Saat banjir menggenangi pematang sawah, keong mas memakan tanaman padi muda hingga ke akar-akarnya. Dalam kondisi banjir, pergerakan keong mas lebih cepat sebab tidak ada pembatas. Apabila lahan dikeringkan keong mas terkumpul disaluran-saluran kecil yang berair, sehingga mudah diberantas baik dengan pestisida maupun secara manual (Dinas Pertanian Tanaman Pangan, Pemerintah Provinsi Jawa Barat, 2010).

\section{Kondisi Pertanaman Padi Saat Ini}

Penanaman padi biasanya dilakukan 2x setahun, yaitu (1) semai Desember, tanam Januari dan panen April/Mei dan (2) tanam Mei/Juni dan panen September/Oktober. Pertanaman (1) selalu terkena banjir pada Januari pertengahan hingga Pebruari akhir, sedangkan pertanaman (2) relatif aman, tidak terkena banjir, meskipun kadangkala terkena kekeringan.

Pertanaman (1) perlu beberapa kali semai dan tanam, perlu benih $2 \mathrm{x}$ lipat karena ada penyulaman atau tanam baru, serta terkena banyak hama terutama keong mas. Pertanaman (2) menghindar banjir, namun waktu tanamnya mundur dengan kendala banyak wereng cokelat dan/atau kekeringan.

Varietas padi yang umum ditanam (Ciherang, Cilamaya Muncul dan "Sogun"/campuran varietas IR64 dan "Denok") berumur 100 hari dari tanam pindah (121130 hari dari sebar) harganya tinggi dipasaran. Introduksi varietas Hibrida anjuran dari pemerintah pernah diterapkan, namun ditinggalkan karena kurang tahan terhadap hama dan penyakit seperti wereng, penggerek batang, dan tungro. Saat ini tidak ada petani yang mau menanam varietas hibrida tersebut walaupun benihnya disubsidi.

Perkiraan hasil rata-rata tanaman padi yang ditanam di tiga Kabupaten pada Januari-Maret adalah sekitar 5-6 ton ha-1 dan tanam pada bulan Juli bisa mencapai 7 ton ha ${ }^{-1}$ (Dinas Pertanian Tanaman Pangan, 2010).

\section{Pemecahan Masalah Menurut Petani/Masyarakat}

Pertanaman I selalu terkena banjir pada Januari pertengahan hingga Pebruari akhir, petani menggeser waktu tanam menjadi Maret (semai Pebruari akhir), panen Juni, dan Pertanaman ke-2 tanam Juli dan panen November/Desember. Dengan cara ini, lahan sawah aman dari kebanjiran. Namun pertanaman musim ke-2 terancam kekeringan.

Menanam bibit tua (berumur 30 hari) dimaksudkan agar tanaman tidak disukai keong mas, atau relatif lebih tahan terhadap serangan keong mas; Bibit tua memiliki batang lebih tinggi, sehingga di tanam lebih cepat meskipun lahan belum kering betul sedangkan bibit muda harus menunggu surutnya air.

Penggunaan varietas toleran rendaman seperti Inpara 3, Inpara 4 (Swarna sub-1) dan Inpara 5 (IR64 sub1) belum dikenal petani. Varietas yang kini ditanam petani hanya tahan rendaman selama 4-7 hari saja, sedangkan varietas-varietas tahan rendaman mampu bertahan 10-14 hari. Mengenai rasa (pera) pada varietas tahan rendaman tertentu (Swarna sub-1 dan sebagainya) tidak dipermasalahkan, asalkan harga jual gabahnya tinggi minimal sama dengan Ciherang (Makarim et al., 2009).

Menurut Dinas Pengelolaan Sumberdaya Air (2009) partisipasi petani dan masyarakat desa dalam menanggulangi banjir baru sebatas pembersihan eceng gondok di saluran pembuangan. Tanaman eceng gondok ini menghambat arus air, menutupi pintu saluran sehingga dapat memperburuk banjir dan mempercepat pendangkalan saluran. Petani mengharapkan adanya perbaikan saluran pembuangan, yaitu memperlebar saluran dari yang sekarang $16 \mathrm{~m}$ menjadi $20 \mathrm{~m}$, dan tinggi saluran $5 \mathrm{~m}$. Dengan rekonstruksi saluran pembuangan tersebut, daya tampung air pembuangan bertambah, sehingga banjir dapat dikurangi dan sumber air di musim kemarau meningkat. 


\section{Studi Kasus di Jawa Tengah (Kabupaten Sragen, Pati dan Demak)}

\section{Permasalahan}

Banjir biasanya terjadi pada pertengahan akhir Desember, Januari, Pebruari atau awal Maret, menyebabkan tanaman padi puso dan terendam selama 20 hari, terutama bila terjadi setelah fase pembungaan menunjukkan rendahnya infiltrasi air ke dalam tanah atau drainase.

Penyebab banjir dari dua faktor input atau sumber pemasukan air, yaitu (a) curah hujan yang cukup tinggi terjadi pada bulan Desember sampai Maret, dan (b) luapan air sungai sering menyebabkan tanggul jebol atau tanah longsor. Satu faktor output yaitu tidak memadainya draenasi atau saluran pembuangan air karena lebih tinggi dibandingkan lahan sawah. Akibatnya air dari saluran melimpah ke sawah-sawah di bawahnya.

Peningkatan populasi hama keong mas dan sundep akibat banjir, pada pertanaman padi yang sudah rusak terkena banjir menjadi mati merupakan masalah utama. Dalam keadaan tergenang pergerakan keong mas lebih lancar sebab tidak ada pembatas keong mas dan memakan tanaman padi muda hingga ke akar-akarnya. Pada lahan yang tidak tergenang keong mas hanya akan berkumpul di saluran-saluran kecil yang berair, sehingga mudah diberantas baik dengan pestisida maupun secara manual (Dinas Pertanian Tanaman Pangan Pemerintah Provinsi Jawa Barat, 2010).

\section{Kondisi Pertanaman Padi Saat Ini}

Pola Tanam di lahan petani yaitu Padi-PadiPalawija. Tanam padi biasanya dilakukan $2 \mathrm{x}$ setahun, yaitu (1) musim Rendeng (Musim I): semai Oktober, tanam November-panen Pebruari/Maret dan (2) Walikan (Musim II): tanam April-panen Juni/Juli. Pertanaman Musim-I selalu terkena banjir pada Januari pertengahan hingga Pebruari akhir, sedangkan pertanaman Musim-II relatif aman, tidak terkena banjir, meskipun kadangkala terkena kekeringan.

Pada Musim tanam I dan II petani menanam padi varietas-varietas padi unggul baru (Ciherang), IR64, Conde dan Mekongga. Masalah utamanya pada musimmusim tersebut yaitu hama keong mas dan sundep dan tikus.

Pada saat banjir pertanaman sedang fase pembungaan (akhir Desember hingga akhir Januari) dan menyebabkan puso sehingga sebagian petani memanen pertanamannya meskipun gabahnya masih separuh berisi. Gabah yang dipanen dengan cara ini, bila digiling dapat menghasilkan beras menir. Jerami yang terendam akibat banjir tidak bisa dijadikan pakan ternak, karena membusuk dan ternak tidak menyukainya sehingga merugikan petani.

\section{Pemecahan Masalah Menurut Petani/Masyarakat}

Menurunkan saluran air irigasi, dengan cara pengerukan. Posisi saluran air diturunkan, menjadi sama atau lebih rendah dari lahan sawah, sehingga tidak terjadi lagi banjir. Saluran yang dibuat dari swadaya masyarakat belum permanen sehingga sering terjadi Longsor dan menyebabkan fungsi saluran terganggu. Bantuan perbaikan saluran air secara permanen agar bisa berfungsi untuk irigasi dan penampung air di musim kemarau dan mengurangi banjir di musim hujan menjadi harapan petani setempat (Dinas Pertanian Tanaman Pangan, 2009; Badan Perencanaan Pembangunan Daerah Kabupaten Subang, 2009).

Tanam padi dilakukan pada bulan September, dan bila normal (tanpa banjir) panen pada akhir Januari hingga awal Pebruari. Apabila banjir terjadi lebih lambat yaitu awal Pebruari, pertanaman sempat panen. Apabila tanam lebih awal (Agustus), pertanaman panen pada pertengahan hingga akhir Desember. Namun masalahnya, waktu tanamnya tidak bisa lebih cepat (dari bulan September) karena air belum masuk sehingga belum bisa tanam. Sumber air berasal dari DAS tidak bisa lebih cepat, karena adanya rehabilitasi waduk antara Juni-Juli dan rutin setiap tahun. Jika pengairan dapat digunakan lebih cepat pertanaman dapat panen secara normal, sebelum terjadi banjir.

Pengenalan varietas padi unggul baru umur lebih genjah seperti Silugonggo, Inpari-1 dengan kualitas gabah relatif sama dan hasil sama atau lebih tinggi daripada Ciherang dan IR64 perlu seleksi varietas spesifik lokasi. Pada musim kemarau (MK) air tanah terasa lebih asin daripada musim hujan $(\mathrm{MH})$. Air sulit digunakan untuk pertanian, termasuk juga untuk minum. Proyek pengairan dengan sistem Embung dan disalurkan ke jaringan pengairan yang dirancang sesuai kebutuhannya. Dengan sistem Embung diharapkan dapat mengatasi kekurangan air untuk pertanaman padi, terutama di MK.

Penggunaan padi hibrida yaitu SR8 (Hibrida PT Pertani) dan PP-1 telah dicoba petani, namun banyak terserang hama penyakit sehingga hasilnya sangat rendah dibandingkan Ciherang atau IR64. Oleh karena itu, peningkatan produksi padi dengan introduksi padi hibrida, sebagai pengganti kehilangan hasil akibat banjir dan kekeringan tidak bisa diandalkan, meskipun potensi hasilnya 9 ton GKP ha-1, kecuali ada hibrida hasil tinggi, tahan hama, penyakit endemik setempat serta tahan kekeringan (Wassman, 2008).

\section{Perubahan Potensi Hasil Padi dan Hasil Akibat Perubahan Suhu Udara}

Dampak perubahan iklim global yang diduga menaikkan suhu udara antara $1.6{ }^{\circ} \mathrm{C}$ dan $6.4{ }^{\circ} \mathrm{C}$ pada tahun 2100 Menurut IPCC (2007) diasumsikan dengan kemungkinan suhu udara rata-rata akan naik sebesar 0.7 ${ }^{\circ} \mathrm{C}$ pada tahun $2020,2{ }^{\circ} \mathrm{C}$ pada tahun 2050 dan $6.4{ }^{\circ} \mathrm{C}$ pada tahun 2100. Perubahan suhu tersebut ditambahkan pada data suhu harian rata-rata 10 tahun (1997-2006) dari Kabupaten Subang dan Pusakanegara untuk mendapatkan prediksi suhu maksimum dan minimum untuk tahun 2020, 2050 dan 2100. Kabupaten Subang dan Pusakanegara mewakili daerah rawan banjir di Provinsi Jawa Barat. Hasil simulasi berupa potensi hasil padi, hasil padi menggunakan varietas tahan rendaman (VTR) dan varietas 
unggul baru (VUB) disajikan pada Gambar 1. Akibat kenaikan suhu udara dari tahun 2006 sebesar 0.7; 2.0; dan $6.4{ }^{\circ} \mathrm{C}$ berturut-turut untuk tahun 2020, 2050 dan 2100 potensi hasil padi diduga turun dari $9,240 \mathrm{~kg} \mathrm{ha}^{-1}$ (tahun 2006) menjadi 8,$997 ; 8,324$ dan $6,909 \mathrm{~kg} \mathrm{ha}^{-1}$. Pada kondisi demikian VUB dan VTR yang pada tahun 20062010 menghasilkan $7,087 \mathrm{~kg} \mathrm{ha}^{-1}$ turun menjadi 6,952; 6,563 dan $5,771 \mathrm{~kg} \mathrm{ha}^{-1}$ akibat kenaikan suhu udara. Selain dampak kenaikan suhu, adanya rendaman pada tahun 2006-2010, 2020, 2050 dan 2100 mengakibatkan hasil padi menurun lebih rendah lagi masing-masing menjadi 3,839; 3,766; 3,555; dan 3,126 $\mathrm{kg} \mathrm{ha}^{-1}$. Adanya varietas baru tahan rendaman yang diasumsikan dapat bertahan terendam selama 6 hari di lapang (potensi ketahanan yang ada sekarang 14 hari), maka dapat menyelamatkan penurunan hasil padi berturut-turut sebesar 3,248; 3,186; 3,008; dan 2,645 $\mathrm{kg} \mathrm{ha}^{-1}$ untuk tahun 2006-2010; 2020; 2050 dan 2100 .

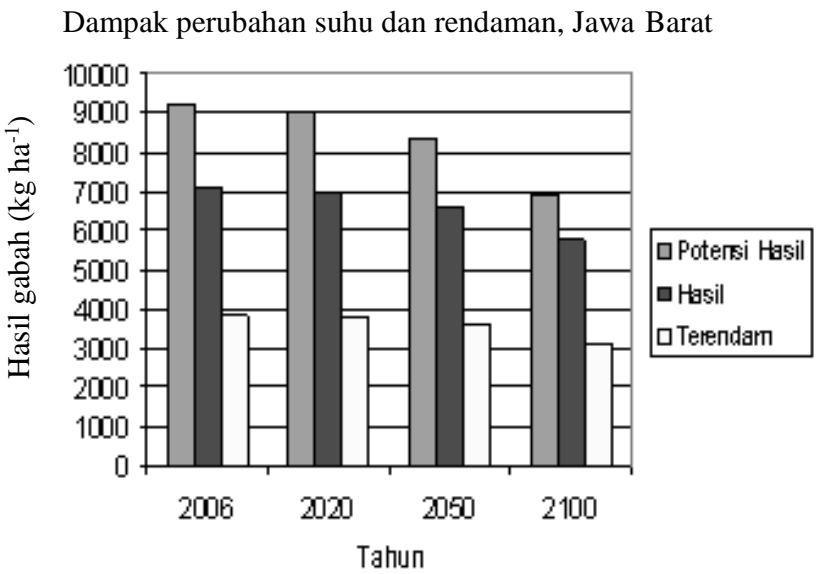

Gambar 1. Perkiraan dampak perubahan suhu dan rendaman (terkait dengan tahun) terhadap potensi hasil padi, dan hasil padi tahan rendaman dan varietas unggul biasa di Jawa Barat.

\section{Dugaan kehilangan hasil dan produksi padi akibat rendaman banjir}

Hasil tanaman padi varietas unggul baru (VUB) dan varietas tahan rendaman (VTR), yang memiliki ketahanan berbeda terhadap lama rendaman, diduga menggunakan model simulasi dinamik RENDAMAN.CSM (Gambar 2). Model di-run dengan menggunakan data iklim Subang rata-rata 10 tahun terakhir (tahun 2000-2009) seperti radiasi surya, suhu maksimum dan minimum, serta curah hujan (Makarim, 2003). Pengaruh banjir di Kabupaten Subang Jawa Barat diduga sama dengan di dua Kabupaten lainnya di Jawa Barat (Karawang dan Indramayu). Berdasarkan hasil simulasi (Gambar 2) hasil gabah kedua varietas (VUB dan VTR) sewaktu tanpa rendaman adalah sama yaitu 5.77 ton $\mathrm{ha}^{-1}$, sedangkan berdasarkan informasi petani hasil gabah di daerahnya berkisar antara 5 dan 6 ton ha ${ }^{-1}$. Ini menunjukkan ketepatan model dalam menduga hasil padi dengan menggunakan input iklim dan data tanah serta jumlah pupuk yang diberikan petani setempat. Berdasarkan dugaan model, perbedaan hasil antara VUB dan VTR mulai nyata setelah lamanya rendaman 6 hari atau lebih. Pada rendaman selama 6 hari hasil gabah VUB turun dari 5.77 ton $\mathrm{ha}^{-1}$ menjadi 3.13 ton ha ${ }^{-1}$ atau turun sebesar 2.64 ton $\mathrm{ha}^{-1}(54.2 \%)$. Besarnya penurunan hasil akan lebih nyata dengan semakin lamanya waktu rendaman. Namun, apabila petani menggunakan varietas tahan rendaman (VTR), maka rendaman selama 6 hari di lahan sawah, tidak akan terjadi kerugian yang berarti.

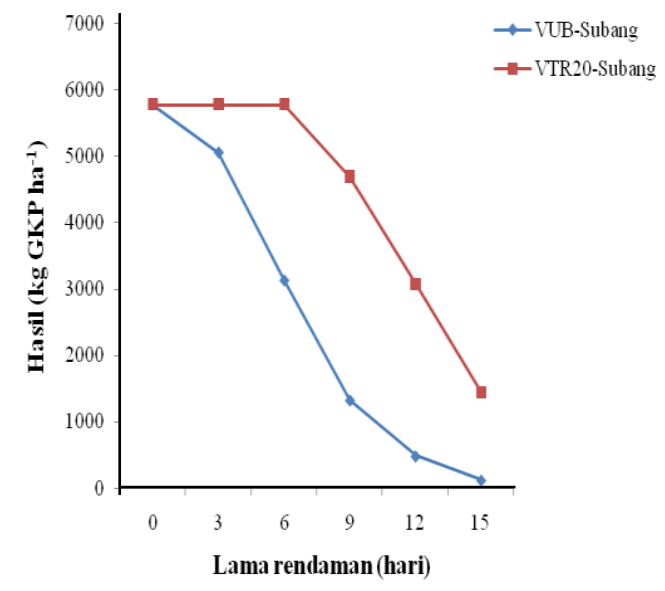

Gambar 2. Dugaan penurunan hasil padi varietas unggul baru (VUB) dan varietas tahan rendaman (VTR) untuk lama rendaman berbeda di Subang, Jawa Barat menggunakan model simulasi.

\section{Inovasi Model Simulasi}

Model RENDAMAN.CSM ini merupakan perbaikan dari model simulasi PADI.CSM dengan menambahkan sub-rutin pengaruh lamanya rendaman terhadap penurunan hasil padi varietas unggul biasa seperti Ciherang, Mekongga, IR64 dan sebagainya dan varietas padi tahan rendaman (VTR). Perbaikan dari PADI.CSM ini mampu menduga hasil padi pada kondisi sawah biasa, sawah rawan rendaman maupun lahan kering/gogo.

Besarnya penurunan hasil gabah akibat rendaman tentunya dapat diduga untuk berbagai lama rendaman, sehingga dengan adanya informasi harga jual gabah, maka besarnya kerugian pada tingkat petani yang mengusahakan tanaman padi, ataupun secara total kerugian di tingkat kabupaten dapat diduga (Tabel 1).

Berdasarkan dugaan model simulasi menggunakan data aktual, besarnya kehilangan hasil/produktivitas tanaman padi akibat banjir/rendaman untuk tiga kabupaten di Jawa Barat adalah 2.65 ton ha-1, kehilangan produksi untuk Kabupaten Subang, Karawang dan Indramayu masing-masing 26 ribu; 46 ribu; dan 34 ribu ton gabah kering panen (Tabel 1). Besarnya kerugian petani akibat banjir pada urutan Kabupaten yang sama adalah Rp. 16.5; 6.8; dan 14.3 juta; sedangkan tiapkabupaten mengalami kerugian sebesar Rp. 68; 112 dan 93 milyar. Besarnya kerugian ini adalah untuk perkiraan antara tahun 2006-2010. 
Tabel 1. Luas lahan sawah terkena banjir, dan dugaan kehilangan hasil dan produksi padi, serta besarnya kerugian di tingkat keluarga petani dan tingkat Kabupaten menggunakan model RENDAMAN.CSM

\begin{tabular}{|c|c|c|c|c|c|c|}
\hline Kabupaten & $\begin{array}{c}\text { Luas lahan } \\
\text { sawah terkena } \\
\text { banjir (ha) }\end{array}$ & $\begin{array}{c}\text { Rata-rata } \\
\text { kehilangan } \\
\text { hasil }\left(\mathrm{kg} \mathrm{ha}^{-1}\right)\end{array}$ & $\begin{array}{c}\text { Harga } \\
\text { gabah } \\
\left(\mathrm{Rp} . \mathrm{kg}^{-1}\right)\end{array}$ & $\begin{array}{c}\text { Kehilangan } \\
\text { produksi } \\
\text { (ton) }\end{array}$ & $\begin{array}{c}\text { Rata-rata } \\
\text { kerugian } \\
\text { petani (Rp. juta) }\end{array}$ & $\begin{array}{c}\text { Rata-rata kerugian } \\
\text { Kabupaten (Rp. juta) }\end{array}$ \\
\hline Subang & 9,849 & 2,645 & 2,606 & 26,051 & 16.5 & 67,895 \\
\hline Karawang & 17,545 & 2,645 & 2,408 & 46,405 & 6.8 & 111,752 \\
\hline Indramayu & 13,004 & 2,645 & 2,700 & 34,396 & 14.3 & 92,868 \\
\hline
\end{tabular}

mendukung pelaksanaan pola tanam; membangun jaringan

Tabel 2. Data dan dugaan luas lahan sawah terkena banjir, besarnya kehilangan produksi padi, serta besarnya kerugian di tiga Kabupaten di Jawa Barat pada tahun 2006-2010, 2015 dan 2020 menggunakan model RENDAMAN.CSM

\begin{tabular}{|c|c|c|c|c|}
\hline $\begin{array}{c}\text { Dampak } \\
\text { banjir }\end{array}$ & Tahun & Subang & Karawang & Indramayu \\
\hline \multirow{3}{*}{$\begin{array}{l}\text { Luas lahan } \\
\text { sawah } \\
\text { terkena banjir } \\
\text { (ha) }\end{array}$} & $2006-2010$ & 9,849 & 17,545 & 13,004 \\
\hline & 2015 & 12,410 & 22,107 & 16,385 \\
\hline & 2020 & 12,804 & 22,809 & 16,905 \\
\hline \multirow{3}{*}{$\begin{array}{l}\text { Kehilangan } \\
\text { produksi } \\
\text { gabah (ton) }\end{array}$} & 2006-2010 & 26,051 & 46,405 & 34,396 \\
\hline & 2015 & 32,824 & 58,470 & 43,339 \\
\hline & 2020 & 33,866 & 60,327 & 44,715 \\
\hline \multirow{3}{*}{$\begin{array}{l}\text { Kerugian } \\
\text { kabupaten } \\
\text { (Rp.juta) }\end{array}$} & $2006-2010$ & 67,895 & 111,752 & 92,868 \\
\hline & 2015 & 85,548 & 140,808 & 117,014 \\
\hline & 2020 & 88,264 & 145,278 & 120,728 \\
\hline
\end{tabular}

Seperti telah diuraikan sebelumnya, luas banjir akan terus meluas hingga tahun 2020. Perluasan areal terkena banjir pada tahun 2015 diperkirakan 1.26 kali luas banjir sekarang, sedangkan untuk tahun 2020 luas terkena banjir menjadi 1.30 . Oleh sebab itu, besarnya kerugian akibat banjir pada tahun 2015 dan 2020 untuk tiga kabupaten di Jawa Barat disajikan pada Tabel 2.

\section{Program, Strategi dan Kebijakan}

Dalam penanggulangan banjir secara umum telah teridentifikasi sebagai berikut: (1) Membuat prioritas pengelolaan, berdasarkan aspek klimatologis, hidrologis, dan agronomis yang mudah dan relatif murah dilakukan secara partisipatif oleh pemangku kepentingan, petani dan petugas lapangan. Prioritas I adalah wilayah yang secara klimatologis sangat rawan banjir, secara hidrologis merupakan Daerah Aliran Sungai (DAS) dan atau jaringan drainase/irigasinya mengalami tingkat kerusakan berat, serta secara agronomis wilayah ini merupakan sentra produksi padi andalan. (2) Menetapkan langkah penanganan secara sistematis, yaitu (a) strategi umum: masing-masing daerah menyusun pola tanam yang lebih rinci dengan memperhitungkan prakiraan iklim, kecukupan debit air, penetapan jenis komoditas yang diusahakan, dan sebagainya. Pola tanam tersebut dievaluasi setiap 2 minggu; (b) strategi khusus: masing-masing wilayah banjir, kelompok tani/P3A beserta petugas Dinas pertanian dan Dinas Pengairan setempat harus melakukan pemeriksaan secara teliti di wilayah kerja masing-masing sebelum tanam, meliputi kesiapan saluran dalam tingkat usaha tani dan atau

jaringan tata air mikro di setiap lokasi untuk perbaiki efisiensi ketersediaan air; (c) introduksi tanaman/varietas tanaman yang tahan rendaman, sambil menunggu perbaikan DAS hulu dan perbaikan infrastruktur penanggulangan banjir; (3) Pengelolaan banjir dan kekeringan pada tingkat kecamatan, dengan prioritas pertama yaitu kecamatan yang sawahnya mengalami banjir dan juga kekeringan pada lokasi yang sama, atau daerah yang sangat rawan banjir dan kekeringan akibat variabilitas/anomali iklim, seperti umumnya terjadi di bagian hilir daerah irigasi (golongan 4, 5 dan seterusnya). Pengelolaan banjir dan kekeringan tersebut dilakukan melalui keterpaduan pendekatan klimatologis, hidrologis dan agronomis dalam program jangka pendek, menengah dan panjang. Selanjutnya dibentuk jadwal tanam yang ketat didukung oleh penyuluh, pemilihan komoditas, dan rencana jejaring kerja.

\section{Langkah antisipatif}

Langkah-langkah antisipasi dalam menghadapi bencana banjir atau kekeringan sebagai berikut: (1) membangun dan memperkuat sistim forecasting untuk banjir dan kekeringan; (2) meningkatkan frekuensi pengamatan curah hujan dan elevasi muka air, untuk peramalan banjir dan kekeringan; (3) mengontrol kondisi dan merehabilitasi bangunan pengendali banjir sebelum masuk bulan-bulan musim hujan dan kemarau; (4) pembentukan satgas siaga banjir; (5) pemeriksaan kesiapan alat komunikasi; (6) penyiapan bahan banjiran dan peralatan; (7) koordinasi dengan Pemda setempat.

\section{SIMPULAN}

Berdasarkan data dan informasi yang dikumpulkan, serta hasil analisisnya maka dapat diambil kesimpulan sebagai berikut:

1. Banjir dan rendaman dapat menurunkan hasil padi secara significant di tiga kabupaten di Jawa Barat dan di tiga kabupaten di Jawa Tengah, serta menyebabkan kerugian besar bagi petani dan pemerintah daerah

2. Kehilangan produksi padi akibat banjir bervariasi antarkabupaten dan antartahun; namun besarnya kehilangan produksi ini diduga akan terus meningkat bila tanpa adanya tindakan antisipasi, penanggulangan dan tindakan adaptasi.

3. Perubahan teknologi diperlukan sebagai tindakan adaptasi terhadap banjir terutama (a) perbaikan varietas tahan rendaman (> 10 hari), dengan harga 
jual gabah tinggi; (b) perbaikan pupuk dan cara pemupukan, serta teknik budidaya lainnya; (c) perbaikan teknologi pengendalian hama, terutama keong mas. Teknologi tersebut harus sudah dirakit sejak sekarang untuk mengantisipasi terjadinya banjir dan rendaman yang lebih lama, luas dan intensif di masa-masa mendatang.

4. Program, Strategi dan Kebijakan dalam menangani banjir dan kekeringan, telah teridentifikasi, baik prioritasnya maupun langkah penanganan secara sistematis.

\section{DAFTAR PUSTAKA}

Badan Perencanaan Pembangunan Daerah Kabupten Subang. 2009. Subang dalam angka tahun 2008. Badan Perencanaan Pembangunan Daerah Kabupten Subang dan Badan Pusat Statistik Kabupaten Subang. 330 hlm.

Departemen Pertanian. 2009. Pengelolaan Banjir dan Kekeringan - Kebijakan Deptan. http://pla.deptan.go.id/rbk/main.html (diakses pada 23 Maret 2009).

Dinas Pertanian Tanaman Pangan, Pemerintah Provinsi Jawa Barat. 2010. Perkembangan dampak perubahan iklim banjir dan longsor pada tanaman padi MH2009/2010 di Jawa Barat. Periode laporan s/d 31 Januari 2010. Dinas Pertanian Tanaman Pangan. Pemerintah Provinsi Jawa Barat. $8 \mathrm{hlm}$.

Dinas Pengelolaan Sumberdaya Air. 2009. Inventarisasi Lokasi Rawan Banjir di Provinsi Jawa Barat. Dinas Pengelolaan Sumber Daya Air, Pemerintah Provinsi Jawa Barat. 42 hlm.

Dinas Pertanian Tanaman Pangan. 2009. Laporan tahunan tahun 2008. Dinas Pertanian Tanaman Pangan
Kabupaten Subang, Pemerintah Kabupaten Subang. $144 \mathrm{hlm}$.

Dinas Pertanian Tanaman Pangan. 2010. Perkembangan Dampak Perubahan Iklim Banjir dan Longsor pada Tanaman Padi MH2009/2010 di Jawa Barat. Periode laporan s/d 31 Januari 2010. Dinas Pertanian Tanaman Pangan. Pemerintah Provinsi Jawa Barat. 8 hlm.

Hart and John. 2006. Global Warming. Microsoft ${ }^{\circledR}$ Encarta 2006 [DVD]. Redmond, WA: Microsoft Corporation, 2005.

IPCC. 2007. Summary for Policymakers. (PDF) Climate Change 2007: The Physical Science Basis. Contribution of Working Group I to the Fourth Assessment Report of the Intergovernmental Panel on Climate Change. Intergovernmental Panel on Climate Change. URL (diakses pada 2 Pebruari 2007).

Makarim, A.K. 2003. Modeling pengelolaan tanaman padi. Dalam B. Suprihatno et al. (Eds.) Buku 2: Kebijakan Perberasan dan Inovasi Teknologi Padi. ISBN 979-8161-85-8. Pusat Penelitian Tanaman Pangan. hlm 181-191.

Makarim, A.K., E. Suhartatik, G.R. Pratiwi dan Ikhwani. 2009. Perakitan teknologi produksi padi pada lahan rawa dan rawan rendaman ( $>15$ hari) untuk produktivitas minimal 7 ton/ha. Laporan Akhir ROPP DIPA 2009 Balai Besar Penelitian Tanaman Padi. 67 hlm.

Wassman, R. 2008. Global climate change: Impact on rice production. Seminar at Indonesian Center for Rice Research. Sukamandi. 